\title{
Ultrasound Efficiency in Relation to Sodium Hypochlorite and Filtration Adsorption in Microbial Elimination in a Water Treatment Plant
}

\author{
Antonio Roberto Crystal Bello ${ }^{1}$, Dejanira de Franceschi Angelis ${ }^{1 *}$ and Roberto Naves \\ Domingos $^{2}$ \\ ${ }^{1}$ Departamento de Bioquímica e Microbiologia; Instituto de Biociências; Universidade Estadual Paulista - UNESP; \\ ${ }^{2}$ Departamento de Física; Instituto de Geociências e Ciências Exatas; Universidade Estadual Paulista - UNESP; \\ dangelis@rc.unesp.br; Av 24A n 1515 ; 13506-900; Rio Claro - SP - Brasil
}

\begin{abstract}
Processes like ultrasound, chlorination and filtration-adsorption were compared to eliminate microorganisms and to adjust established parameters of public drinking water. A mini water treatment plant (WTP-CB), in pilot scale, was projected and built to evaluate each process influence as: decontamination, coagulation-flocculation, sedimentation and filtration. Total and fecal coliforms, Escherichia coli and heterotrophic bacteria and physic/chemical parameters were quantified from water. Ultrasound, chlorination and filtration-adsorption were efficient to inactivate and/or eliminate bacteria. Ultrasound decontamination in addition to coagulationflocculation, sedimentation and filtration, could be considered as an alternative treatment water solution where prechlorination, coagulation-flocculation, sedimentation and filtration were used. The chlorination itself was efficient in inactivating bacteria despite of the coagulation-flocculation process; however, in the absence of the coagulation process, the resultant water did not achieve the established parameters. The filtration-adsorption was an important process to eliminate bacteria, showing that the filter retained particles, suspended solids, besides chemical substances and microorganisms.
\end{abstract}

Key words: Water; Filtration; Microorganisms, Ultrasound, Chlorination

\section{INTRODUCTION}

Coagulation is the formation process of clot by means of a coagulant reaction in contact with water. Coagulation objective is to transform impurities such as fine colloidal suspension, suspended solids and microorganisms, in bigger particles called flocks, which can be removed by sedimentation, flotation and/or filtrationadsorption. The parameters that determine an efficient coagulation are $\mathrm{pH}$, kind of coagulant, rapid mix of coagulant, water temperature, zeta potential and others. The most used coagulants are aluminum sulfate, ferric chloride, ferrous sulfate, ferric sulfate, polychlorinated aluminum, sulfate chlorinated ferrous. Flocculation is a process where particles in liquid medium are forced to move, being attracted by each other to form flocks. The continuous movement makes the flocks thicker for a farther sedimentation. There are two kinds of flocculation systems, the hydraulic (chicane, granular medium) and the mechanic (mechanic mixers) (Di Bernardo, 1993).

\footnotetext{
Author for correspondence
} 
The filtration-adsorption phase removes suspended particles, colloids, microorganisms and chemical compounds from water. The filters present their own characteristics depending on the filtering medium, which can be formed by sand layers, or activated carbon and sand layers, or diatomaceous earth (Leme, 1990).

The filtration phases are chemical, physical, biological and biochemical phenomena (Viana, 1997). The adsorption process includes the substance to be adsorbed and the adsorbing surface; the intensity of the effect depends on the temperature, the adsorbent nature and subdivision, and concentration of the adsorbed substance.

The water decontamination process is fundamental to eliminate microorganisms and can be done by chemical substances, like sodium hypochlorite, gaseous chlorine, calcium hypochlorite, chlorine dioxide, chlorinated lime, ozone, ammonium quaternaries. In gaseous chlorine or sodium hypochlorite solution $(\mathrm{NaClO})$ there is the formation of hypochlorous acid and hypochlorite ion, in aqueous solutions, which present disinfectant action on microorganisms in general (Haas, 1999). The inconvenient of the sodium hypochlorite or gaseous chlorine application is that depending on the quality of the raw water, chlorinated compounds like the trihalo methanes (THM) may be formed in harmful concentrations to human health (Condie, 1990).

The ultrasound (US) consists of a soundless longitudinal mechanical wave, with frequency above $20000 \mathrm{~Hz}$ where energy is transmitted by the vibration of the molecules in the environment where the wave is being spread. Scherba et al. (1991) showed the efficacious germicide action, in a frequency of $26000 \mathrm{~Hz}$ applied on aqueous bacterial suspension. The US effect in the biological area can may be due to the high radiation potential, which can dislocate, distort and/or re-orientate intercellular particles or even cells in their normal configurations (Fontana, 1996).

The cavitations generated by US can induce electrical and chemical phenomena, besides mechanical destruction; the cavitations produce intense shock waves, instantaneous temperature and pressure increase, and chemical effects in the medium, generated by the cavities or micro bubbles (Guirro, 1999). US effect on Escherichia coli $\mathrm{BH} 100$, showed the bactericide effect of US at $1 \mathrm{MHz}$ frequency. Phull et al. (1997) studied the microbial destruction or inactivation by US. The results indicated that the US could be efficacious in water decontamination. An increase in the US power increased bacterial cell destruction, and high US frequency waves were more efficient to the process of water decontamination than low US frequencies. Twenty $\mathrm{KHz}$ US decreased cell viability of Saccharomyces cerevisae when applied under controlled laboratory conditions. US could be used as microorganism viability control method in liquid effluents and contaminated water sanitation (Tomasin, 2001). US may also be applied to remove humic substances from raw water before chlorination by conventional coagulation and filtration process using aluminum sulfate (Chemat et al., 2001).

\section{MATERIALS AND METHODS}

Raw Water: The raw water samples were collected in a stream - Ribeirão Claro, located at Edmundo Navarro de Andrade State Forest - Rio Claro City (SP).

Pilot WTP CB: The pilot water treatment plant was built following the CB Advisory and Training S/C Ltda. The WTP has an entrance compartment, granular flocculating medium, chicanes, sedimentation basin and rapid filter in descending flow.

Ultrasound: Sonic of Materials Vibra Cell - model VCX 600, $20 \mathrm{~Hz}$ frequency, 600-Watts power.

Other Equipments: $\mathrm{pH}$ meter, submersed water pump, thermometer, conductivity meter, analytical balance, incubator, oven, colonies counter, tray sealer, spectrophotometer Hach Dr 2000, lab glasses, sterilized flasks, bacterial counting tray Quanti - Tray 2000.

Reagents and Culture Medium: Ferric chloride solution (coagulant), sodium hydroxide solution, sodium hypochlorite solution, Hach reagents for analyzing iron and residual free chlorine, Colilert reagents for determining total and fecal $E$. coli coliforms, culture medium Plate Count Agar (PCA) (Difco, 1984).

The raw water is pumped from the reservoir by an immerse pump to the entrance box of WTP - CB, and with the aid of a separation funnel coagulant ferric chloride solution and alkalizing sodium hydroxide are added. The flocculation system used at compact WTP was the chicanes and granular medium. An electrode $\mathrm{pH}$ meter was used between the chicanes of the flocculation system to continuously control the $\mathrm{pH}$ of the coagulation 
process. The flocculated water gets into the sedimentation basin and the supernatant (clarified water) drains off by three receivers waterway that flow into the rapid filter formed by activated carbon layers, fine, medium and coarse sand, and gravel. The filtering medium was periodically washed by a reverse current of wash water.

For sodium hypochlorite decontamination, the raw water received continuous flux of $\mathrm{NaClO}$ solution, and ferric chloride solution. After coagulation/flocculation the water was decanted and filtered (Table 1 - Experiment A).

During the US decontamination process, the raw water received, in continuous flow, ferric chloride and sodium hydroxide solutions. After coagulation/flocculation, the water passed through the sedimentation basin and filter and after, through the decontamination process with US (Table 1 - Experiment B).

During filtration/adsorption process, the raw water in continuous flow received ferric chloride and sodium hydroxide solutions and after the coagulation/flocculation, the clarified water was collected by the waterway going to pour out into the filter containing activated carbon, sand and gravel (Table 1 - Experiment C).

All tests were performed as in Table 1 to study individual and/or associated processes.

Table 1 - Diagram of experimental conditions A, B, C, D, E, F, G, H, using the compact WTP - CB to Rio Claro Stream water treatment.

\begin{tabular}{|c|c|c|c|c|c|c|c|}
\hline \multirow[b]{3}{*}{ Experiments } & \multicolumn{7}{|c|}{ Experimental Conditions } \\
\hline & Water & \multirow[b]{2}{*}{ alkalinized } & \multirow[b]{2}{*}{ coagulated } & \multirow[b]{2}{*}{ chlorinated } & \multirow[b]{2}{*}{ settled } & \multirow[b]{2}{*}{ filtrated } & \multirow{2}{*}{$\begin{array}{l}\text { Ultra- } \\
\text { sound } \\
\text { us }\end{array}$} \\
\hline & $\begin{array}{c}\text { Rio Claro } \\
\text { stream }\end{array}$ & & & & & & \\
\hline $\mathbf{A}$ & + & + & + & - & + & + & - \\
\hline $\mathbf{B}$ & + & + & + & - & + & + & + \\
\hline $\mathbf{C}$ & + & + & + & + & + & + & - \\
\hline $\mathbf{D}$ & + & + & + & - & + & - & + \\
\hline $\mathbf{E}$ & + & + & + & + & + & - & - \\
\hline $\mathbf{F}$ & + & - & - & - & + & + & - \\
\hline $\mathbf{G}$ & + & - & - & - & + & - & + \\
\hline $\mathbf{H}$ & + & - & - & + & + & - & - \\
\hline
\end{tabular}

(+) applied condition

$(-)$ not applied condition

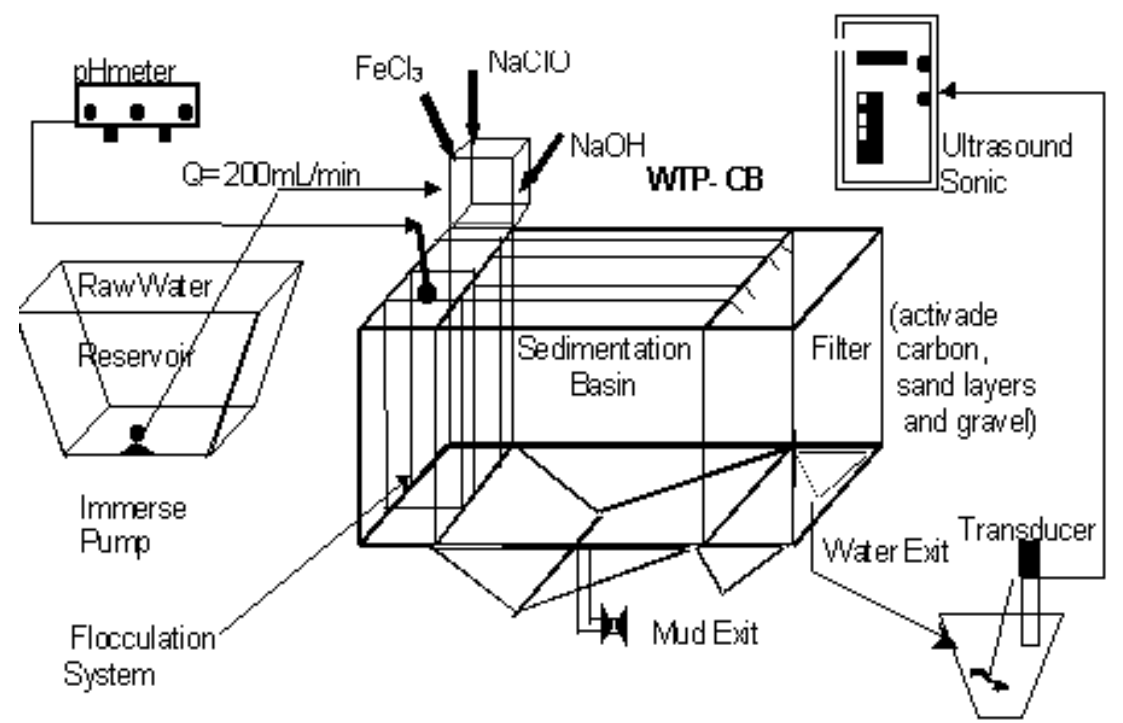

Figure 1 - Diagram indicating the process of compact WTP-CB experiments 
The resultant water of the studied process was analyzed for the following parameters: $\mathrm{pH}$, apparent color, turbidity, electrical conductivity, salinity, temperature, dissolved total solids (DTS), iron, residual free chloride, suspended solids (SS), total coliforms (TC), fecal coliforms E. coli (FC) and heterotrophic bacteria (HB). Three analyses were made for each parameter and arithmetic average was made as shown in Table 2. All the analysis complied with the Standard Methods for the Examination of Wastewater (Clesceri et al. 1998). To count TC and FC the Collilert technique and the bacterial counting tray Quanti - Tray 2000 Idexx were used. The "pour plate" technique to count forming colonies $(\mathrm{CFU} / \mathrm{mL})$ was used to determine HB.

As reference to drinkable water, the Health Ministry $\mathrm{n}^{\circ}$ 1469/00 Decree - Control and Vigilance of drinking water quality for human consumption was utilized.

For obtaining the reduction percentage in the parameters, the expression was:

$$
\% \text { reduction }=\frac{(\mathrm{I}-\mathrm{F})}{\mathrm{I}} \times 100 \%
$$

where $\mathrm{I}=$ value of parameter in the raw water; $\mathrm{F}$ $=$ value of parameter in the water later treatment process.

Table 3 shows the results from reductions.

\section{RESULTS AND DISCUSSION}

Table 2 shows the results from treatments A, B, D, E, F, G and H, used at the WTP-CB for the water from the Edmundo Navarro de Andrade State Forest stream. For the utilization of the coagulation/flocculation, sedimentation and filtration (Process A), it was observed that the resultant water presented a satisfactory quality for physical-chemical and bacteriological parameters. The apparent color reduced an average of $94.7 \%$; turbidity $96.0 \%$; suspended solids $96.2 \%$ and iron $95.2 \%$. The medium average reduction of TC was $99.9 \%$, FC $99.8 \%$ and HB $95.6 \%$.

Process B used coagulation/flocculation, sedimentation, filtration and US, and its results were considered better than in process $\mathrm{A}$, especially concerning the bacterial population reduction. The apparent color reduced 95.5\%; turbidity $95.9 \%$; suspended solids $96.4 \%$; iron $95.1 \%$; TC $99.9 \%$; FC $99.9 \%$ and HB $97.4 \%$.
Pre-chlorination, coagulation/flocculation, sedimentation and filtration were utilized in process C. The resultant water also presented satisfactory quality. The average percent reduction of apparent color was $97.1 \%$, turbidity $96.9 \%$, suspended solids $97.7 \%$ and iron $95.9 \%$. The reducing average percent of TC was $99.9 \%$, FC $99.9 \%$ and $\mathrm{HB}$ 99.9\%. The results from treatments $\mathrm{B}$ and $\mathrm{C}$ were similar. In this case, it was better to use the US water decontamination techniques (B process without pre-chlorinated) to avoid chlorinated compound formation likes THM.

$\mathrm{D}$ and $\mathrm{E}$ processes, where the coagulation/flocculation, sedimentation and US or pre-chlorination were used, showed reduction of 99.9\% in bacterial population. These processes showed that without the filter comprising activated carbon and sand, the resultant water presented physical-chemical parameters above the maximum values established by the law, as shown in Table 2 . $\mathrm{F}, \mathrm{G}$ and $\mathrm{H}$ processes, where the filtration, US and chlorination techniques were evaluated individually, bacterial population reduction was observed, however, without the coagulation/flocculation and sedimentation processes, the resultant water quality did not correspond to the established values by the Health Ministry Decree $\mathrm{n}^{\circ}$ 1469/00.

Comparing the two tests $\left(4^{\circ}\right.$ and $\left.5^{\circ}\right)$ in the $G$ process, it was seen that the US was more efficient to decontaminate when there were suspended solids or formed flocks in the water. The $G$ process had $33 \mathrm{mg} / \mathrm{L}$ suspended solids, TC < $81.7 \%$ reduction, $\mathrm{FC} 48.6 \%$ and $\mathrm{HB} 99.6 \% ; 5^{\circ}$ experiment: $8 \mathrm{mg} / \mathrm{L}$ suspended solids, TC $19.3 \%$ reduction, FC $22.3 \%$ and $\mathrm{HB} 70.6 \%$.

The coagulation/flocculation, decantation and filtration processes were fundamental to obtain quality water, which was observed by the turbidity reduction, apparent color, iron, suspended solids and bacteria. The chlorination process with sodium hypochlorite solution was efficient for bacterial inactivation, despite the use of coagulation/flocculation. However, to attend the physical-chemical parameters, it was necessary to coagulate/flocculate settle and filter the water.

The US decontamination process could be used with the coagulation, flocculation, decantation and filtration, giving the possibility of eliminating bacteria present in the raw water. The US indicated more efficiency on bacteria elimination when the water had bigger amounts of suspended 
solids or formed flocks. The US could be used in the pre-decontamination and, in this case, would be applied sodium hypochlorite only afterdecontamination, to keep some residual chloride on the drink water as the legislation recommends.

To the filtration process or US without coagulating and alkalinizing applications, there were less efficiency on bacteria elimination as well in turbidity, apparent color, iron and raw water suspended solids reduction.

Ferric chloride induces the coagulation at $\mathrm{pH}$ between 5.0 and 11.0. In the WTP - CB experiments with raw water from the Edmundo Navarro de Andrade State Forest stream - Ribeirão Claro, values of $\mathrm{pH}$ between 8.5 and 9.5 showed more appropriated to produce flocks of higher sedimentability.

At the coagulation/flocculation, decantation and filtration there are a co-relation between the bacteria quantity and the turbidity, apparent color and suspended solids, as shown in table 3 . In accordance with these parameters reduction, there are bacterial decreases, what can help on the water bacteriological control.

Table 2 - Mean values of the analyses in different raw water treatment processes all the Ribeirão Claro, realized at compact WTP - CB.

\begin{tabular}{|c|c|c|c|c|c|c|c|c|c|c|c|c|c|c|}
\hline $\begin{array}{l}\text { Experimental } \\
\text { conditions }\end{array}$ & $\begin{array}{l}\text { Experiment } \\
\text { number }\end{array}$ & $\mathrm{pH}$ & $\begin{array}{c}\text { Apparent } \\
\text { color } \\
\text { (PtCo) }\end{array}$ & $\begin{array}{c}\text { Turbidity } \\
\text { (NTU) }\end{array}$ & $\begin{array}{l}\text { DTS } \\
\text { (mg/L) }\end{array}$ & $\begin{array}{l}\text { Eletric } \\
\text { Cond. } \\
\mu \mathrm{S} / \mathrm{cm}\end{array}$ & $\begin{array}{l}\text { Salinity } \\
(\mathrm{o} / \mathrm{oo})\end{array}$ & $\begin{array}{l}\text { Temp. } \\
\left({ }^{\circ} \mathrm{C}\right)\end{array}$ & $\begin{array}{c}\mathrm{Fe} \\
(\mathrm{mg} / \mathrm{L})\end{array}$ & $\begin{array}{c}\mathrm{S} . S \\
(\mathrm{mg} / \mathrm{L})\end{array}$ & $\begin{array}{c}\text { Free res. } \\
\text { chloride } \\
\text { (mg/L) }\end{array}$ & $\begin{array}{c}\text { TC } \\
\text { MPN } \\
100 \mathrm{~mL}\end{array}$ & $\begin{array}{c}\mathrm{FC} \\
\mathrm{MPN} \\
100 \mathrm{~mL}\end{array}$ & $\begin{array}{c}\mathrm{HB} \\
\mathrm{CFU} \\
\mathrm{mL}\end{array}$ \\
\hline $\begin{array}{c}\text { RAW } \\
\text { WATER }\end{array}$ & & 6.30 & 1771 & 453 & 31 & 64.8 & 0.0 & 248 & 2.19 & 93 & 0.00 & 22.900 & 3100 & 48.000 \\
\hline A & 1 & 6.82 & 36 & 6 & 95 & 201 & 0.1 & 26.4 & 0.11 & 2 & 0.00 & $<1$ & $<1$ & 220 \\
\hline$B$ & & 6.81 & 38 & 6 & 96 & 202 & 0.1 & 27.5 & 0.12 & 2 & 0.00 & $<1$ & $<1$ & 18 \\
\hline C & & 6.97 & 35 & 7 & 242 & 507 & 0.2 & 25.8 & 0.10 & 2 & 0.05 & $<1$ & $<1$ & 25 \\
\hline $\begin{array}{c}\text { RAW } \\
\text { WATER }\end{array}$ & & 6.89 & 495 & 87 & 28 & 59.7 & 0.0 & 24.7 & 1.95 & 40 & 0.00 & 21.113 & 557 & 4833 \\
\hline A & 2 & 6.64 & 38 & 5 & 54 & 113.5 & 0.1 & 24.7 & 0.12 & 2 & 0.01 & 6,4 & $<1$ & 600 \\
\hline B & & 6.53 & 34 & 6 & 54 & 113.1 & 0.1 & 26.9 & 0.08 & 2 & 0.00 & 5,9 & $<1$ & 250 \\
\hline $\mathrm{C}$ & & 9.30 & 19 & 4 & 863 & 1753 & 0.9 & 24.9 & 0.07 & 1 & 3.47 & $<1$ & $<1$ & 0 \\
\hline $\begin{array}{c}\text { RAW } \\
\text { WATER }\end{array}$ & & 7.10 & 243 & 42 & 30 & 62.9 & 0.0 & 24.4 & 1.82 & 23 & 0.01 & 6990 & 270 & 2867 \\
\hline A & 3 & 9.30 & 15 & 2 & 205 & 430 & 0.2 & 26.5 & 0.06 & 1 & 0.00 & $<1$ & $<1$ & 6 \\
\hline $\mathrm{D}$ & & 9.50 & 104 & 20 & 423 & 881 & 0.4 & 28.1 & 3.03 & 6 & 0.00 & 3,1 & $<1$ & 5 \\
\hline$E$ & & 9.19 & 105 & 17 & 586 & 1209 & 0.6 & 26.4 & 4.32 & 6 & 3.37 & $<1$ & $<1$ & 5 \\
\hline $\begin{array}{l}\text { RAW } \\
\text { WATER }\end{array}$ & & 6.99 & 247 & 45 & 28 & 60.2 & 0.0 & 27.5 & 1.91 & 33 & 0.01 & 13.227 & 1340 & 250.000 \\
\hline$F$ & 4 & 7.76 & 172 & 29 & 35 & 73.5 & 0.0 & 27.6 & 1.53 & 4 & 0.00 & $>2419.2$ & 419.7 & 933 \\
\hline $\mathrm{G}$ & & 7.24 & 221 & 38 & 33 & 69.6 & 0.0 & 27.9 & 1.85 & 28 & 0.01 & $>2419.2$ & 689.0 & 917 \\
\hline $\mathrm{H}$ & & 8.64 & 234 & 38 & 136 & 287 & 0.1 & 27.7 & 1.83 & 29 & 0.09 & $<1$ & $<1$ & 28 \\
\hline $\begin{array}{c}\text { RAW } \\
\text { WATER }\end{array}$ & & 7.03 & 137 & 23 & 25 & 53.7 & 0.0 & 21.9 & 1.48 & 8 & 0.00 & 3197 & 300 & 1133 \\
\hline$F$ & 5 & 7.79 & 102 & 19 & 48 & 100.6 & 0.0 & 23.2 & 1.25 & 3 & 0.00 & 48 & $<1$ & 27 \\
\hline $\mathrm{G}$ & & 7.11 & 122 & 22 & 28 & 59.5 & 0.0 & 23.5 & 1.36 & 7 & 0.00 & 2580 & 233 & 333 \\
\hline $\mathrm{H}$ & & 8.36 & 111 & 21 & 130 & 274 & 0.1 & 22.9 & 1.40 & 7 & 0,07 & $<1$ & $<1$ & 1 \\
\hline
\end{tabular}


Table 3 -Values of the percentage reduction parameters.

\begin{tabular}{|c|c|c|c|c|c|c|c|c|}
\hline $\begin{array}{l}\text { Experimental } \\
\text { conditions }\end{array}$ & $\begin{array}{c}\text { Experiment } \\
\text { number }\end{array}$ & Turbidity & $\begin{array}{c}\text { Apparent } \\
\text { color }\end{array}$ & SS & Iron & TC & FC & $\mathrm{HB}$ \\
\hline \multirow{3}{*}{ 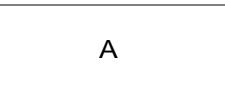 } & 1 & 98.7 & 98.0 & 97.8 & 95.0 & 99.9 & 99.9 & 99.5 \\
\hline & 2 & 94.3 & 92.3 & 95.0 & 93.8 & 99.9 & 99.8 & 87.6 \\
\hline & 3 & 95.2 & 93.8 & 95.7 & 96.7 & 99.9 & 99.6 & 99.8 \\
\hline \multirow{3}{*}{ B } & 1 & 98.7 & 97.9 & 97.8 & 94.5 & 99.9 & 99.9 & 99.9 \\
\hline & 2 & 93.1 & 93.1 & 95.0 & 95.9 & 99.9 & 99.9 & 94.8 \\
\hline & 1 & 98.5 & 98.0 & 97.8 & 95.4 & 99.9 & 99.9 & 99.9 \\
\hline $\mathrm{C}$ & 2 & 95.4 & 96.2 & 97.5 & 96.4 & 99.9 & 99.8 & 100.0 \\
\hline $\mathrm{D}$ & 1 & 52.4 & 57.2 & 73.9 & -66.5 & 99.9 & 99.9 & 99.9 \\
\hline \multirow[t]{2}{*}{$E$} & 1 & 59.5 & 56.8 & 73.9 & -137.4 & 99.9 & 99.9 & 99.9 \\
\hline & 1 & 35.6 & 30.4 & 87.9 & 19.9 & $<81.7$ & 68.7 & 99.6 \\
\hline \multirow[t]{2}{*}{$\mathrm{F}$} & 2 & 17.4 & 25.5 & 62.5 & 15.5 & 98.5 & 99.9 & 97.6 \\
\hline & 1 & 15.6 & 10.5 & 15.2 & 3.1 & $<81.7$ & 48.6 & 99.6 \\
\hline \multirow[t]{2}{*}{$\mathrm{G}$} & 2 & 4.3 & 10.9 & 12.5 & 8.1 & 19.3 & 22.3 & 70.6 \\
\hline & 1 & 15.6 & 5.3 & 12.1 & 4.2 & 99.9 & 99.9 & 99.9 \\
\hline $\mathrm{H}$ & 2 & 8.7 & 19.0 & 12.5 & 5.7 & 99.9 & 99.9 & 99.9 \\
\hline
\end{tabular}

\section{ACKNOWLEDGEMENTS}

We thank the National Scientific and Technological Development Council - CNPq/CT Hidro Brasil, for supporting this research.

\section{RESUMO}

Comparou-se diferentes processos: ultra-som, cloração e filtração/adsorção para eliminação de microrganismos e adequação de outros parâmetros exigidos para água de abastecimento público. Para avaliar a influência de cada processo: desinfecção, coagulação/floculação, decantação e filtração foi projetada e construída uma Estação de Tratamento de Água (ETA-CB) em escala piloto. Foram avaliados coliformes, bactérias heterotróficas e parâmetros físico/químicos. Ondas ultra-sônicas, cloração e filtração/adsorção mostraram-se eficientes na inativação e/ou eliminação de bactérias. O processo de desinfecção com ultrasom juntamente com a coagulação/floculação, decantação e filtração, pode ser considerado como um tratamento alternativo do processo tradicional onde utiliza-se pré-cloração, coagulação/floculação, decantação e filtração. A cloração mostrou-se eficiente na inativação de bactérias, independente da aplicação do processo de coagulação/floculação, porém na ausência desse processo à água resultante não atingiu a especificação de potabilidade. A filtração/adsorção mostrou-se importante na eliminação de bactérias, evidenciando que o filtro retém partículas, sólidos suspensos, substâncias químicas e microrganismos.

\section{REFERENCES}

Chemat, F.; Teunissen, P. G. M.; Chemat, S. and Bartels, P. V. (2001), Sono-oxidation treatment of humic substances in drinking water. Ultrasonics Sonochemistry, 8, 247 - 250.

Cleasby, J. L. and Logsoon, G. S. (1999), Water quality and treatment. American Water Works Association, New York: McGraw-Hill. pp. 8.1-8.91.

Clesceri, L. S.; Greenberg, A. E. and Eaton, A. D. (1998), Standard methods for the examination of water and wastewater. Washington, D.C.: American Public Health Association, American Water Works Association, Water Environment Federation.

Condie, L. W. (1990), Water chlorination chemistry environmental impact and health effects. Toxicological Effects Associated with Drinking Water Disinfectant and their by Products, 6, 281-191.

Di Bernardo, L. (1993), Métodos e técnicas de tratamento de água. Rio de Janeiro: Associação Brasileira de Engenharia Sanitária Ambiental ABES. pp. 402-459.

Difco (1984), Dehydrated culture manual: media and reagents for microbiology. Detroit: DIFCO Laboratories. pp. 679.

Fontana, R. (1996), Efeitos do ultra-som de alta intensidade na ativação e inativação de esporos bacterianos. Dissertação (Mestrado), Universidade Estadual Paulista, Rio Claro, Brasil.

Guirro, E. C. O. (1999), Bioefeitos induzidos por ultrasom em Staphylococus aureus e Escherichia coli estudo in vitro. Tese (Doutorado), Universidade Estadual Paulista, Rio Claro, Brasil.

Haas, N. C.; Snoeyink, L. V. and Summers, R. S. (1999), Water quality and treatment: a handbook of community water supplies. American Water Works Association. New York: McGraw-Hill.

Leme, F. P. (1990), Teoria e técnicas de tratamento de água. Rio de Janeiro: ABES. pp. 540-564. 
Haas, N. C.; Snoeyink, L. V. and Summers, R. S. (1999), Water quality and treatment: a handbook of community water supplies. American Water Works Association. New York: McGraw-Hill.

Leme, F. P. (1990), Teoria e técnicas de tratamento de água. Rio de Janeiro: ABES. pp. 540-564.

Health Ministry (2000), Normas e padrão de potabilidade de águas destinadas ao consumo humano. Portaria n. ${ }^{\circ}$ 1469, de 29 de dezembro de 2000. Brasil.

Phull, S. S.; Newman, J. P.; Lorimer, J. P.; Pollet, B. and Mason, T. J. (1997), The development and evaluation of ultrasound in the biocidal treatment of water. Ultrasonics Sonochemistry, 4, 157-164.

Scherba, G.; Weigel, R. M. and O'Brien Jr., W. D. (1991), Quantitative assessment of the germicidal efficacy as ultrasonic energy. Applied and Environmental Microbiology, 57, 2079-2087.

Tomasin, A. C. (2001), Biorresistência e efeitos causados pela ação acoplada da irradiação ultrasônica e processo eletrolítico no aproveitamento da levedura. Dissertação (Mestrado), Universidade Estadual Paulista, Rio Claro, Brasil.

Vianna, M. R. (1997), Hidráulica aplicada às estações de tratamento de água. Minas Gerais: Imprimatur Artes. 